\title{
THE EFFECT OF INTERNET USE HABIT TOWARD ENGLISH ACHIEVEMENT: SURVEY STUDY IN SMP AL AZHAR 8 BEKASI
}

\section{Okfida Yani Syaf}

Sekolah Tinggi Bahasa Asing (STBA) Cipto Hadi Pranoto

Email: okfidayani240@gmail.com

\begin{abstract}
Students nowadays interact more frequently through the internet using English. As an international language, English is used by most internet users, both by application companies and social networks, as well as by users. Internet usage can be more easily obtained, especially in big cities. This affects the students' way of thinking, learning and behaving because they can learn everything easily and quickly through online media available at the internet. The aim of this research is to show the effect of internet use habit on English achievement for class VIII students at SMPI Al Azhar 8 in Bekasi. This research based on survey methods using technical correlational analysis. While the data and information were obtained by a questionnaire. The sample is taken with purposive sampling technique that is 44 students. Based on the results of the study, it can be concluded that: There is a significant effect of the habit of interacting through the internet on the English achievement. This is evidenced by the acquisition of the results of the Sig. 0,000 $<0,05$ dan $t$ value $=4,365$ which means there is a significant effect.
\end{abstract}

Keywords: habit; internet; english achievement

\section{Introduction}

Nowadays, internet has developed, become an important part of human life and cannot be separated from communication. Along with the rapid development of technology and communication via the internet, the use of English has also advanced rapidly, especially in the exchange of information on the internet (Jauhari, 2010). The world community more often interacts and exchanges information via electronic mail (e-mail), internet sites (Websites), as well as social media applications such as Facebook, WhatsApp, Twitter, Instagram, etc.

In this era, students can learn quickly because of the stimulus gained from multimedia such as mobile phones, computers, internet, cable TV, audio visual aids, etc (Jatileni \& Jatileni, 2018). Students can easily visit web pages or blogs, search for information or download music, videos, films or data easily. In big cities most students own a cell phone and interact with everyone directly anywhere, anytime.

A study published recently on (Panji, 2014) had recorded data on the results of the study entitled "Safety of the Use of Digital Media in Children and Youth in Indonesia" conducted by the UN agency for children, UNICEF, together with partners, including the Ministry of Communication and Information and Harvard University, USA. The 
study traced online activities from a sample of children and adolescents involving 400 respondents aged 10 to 19 across Indonesia and representing urban and rural areas. As many as 98 percent of children and adolescents claim to know about the internet and 79.5 percent of them are internet users. While about 20 percent of respondents do not use the internet. The main reason is that they don't have the tools or infrastructure to use the internet or they are forbidden by parents to use the internet (Hariyadi \& Arliman, 2018).

This study also found that there are three motivations for children and adolescents to access the internet, namely to find information, to connect with friends (old and new) and for entertainment. Information seeking is often driven by school assignments, while the use of social media and watching or enjoying entertainment are driven by personal needs.

Dogruera, Eyyam and Menevis concluded that the Internet can be used as a tool to learn the latest news all around the world as well as getting any kind of information that serves different purposes (Dogruer, Eyyam, \& Menevis, 2011). The internet is the source of spreading information quickly to a large audience and of going beyond the limitation of time and space. It is very obvious that the Internet provides not only social connection and entertainment, but also academic and scientific information. The study also found that the majority of the students believed they can use the Internet as an educational tool. Only a very little participants stated that they were not able to use it for educational purposes. Therefore, it can be assumed that the Internet may be used by students as well as teachers as one of learning media (Dogruer et al., 2011).

Meanwhile, English, as one of international languages, is used by most internet users such as application companies, social networks, and its users. It cannot be denied that students currently interact more often via the internet using English. This interaction may become a habit among the students (Riyana \& Syaifudin, 2014).

Habits can be defined as routines of mostly subconscious regular repetition behavior. It helps students organize their efforts to solve problems, develop skills, acquire knowledge and completion of school obligations (Urh \& Jereb, 2014).

From the discussion above, it can be concluded that the students' internet use habit may affect to their English achievement. With the use of the internet as a source of information and high learning motivation, students are expected to obtain good learning achievements

\section{Method}

In this research, the writer uses survey research method. Survey is a method commonly used in research in the field of social science (Yuliansyah, 2016). Assumed that a survey can be used when a researcher is interested in the opinions of a large group of people about a particular topic or issue. They then ask a number of questions, all related to the issue, to find the answers (Fraenkel, Wallen, \& Hyun, 2012).

The major purpose of surveys is to describe the characteristics of a population. In essence, what researchers want to find out is how the members of a population 
distribute themselves on one or more variables such as age, ethnicity, religious preference, attitudes toward school (Fraenkel et al., 2012)

According to (Fraenkel et al., 2012), There are four basic ways in collecting data for a survey research. The study was conducted in, one of the basic ways, 'Direct Administration to a Group' method. It is used whenever a researcher has access to all (or most) of the members of a particular group in one place. The instrument, such as questionnaires, is administered to all members of the group at the same time and usually in the same place.

For this research, the students were asked to complete a set of questionnaires in their classrooms. On the other hand, the students' English achievement was obtained from the score of Final English Assessment, PAS, that was kept by the teacher. The advantage of this approach is the high rate of response and the lower cost factor. Moreover, the researcher has an opportunity to explain the study and answer any questions that the respondents may have before they complete the questionnaire.

This research was conducted at SMP Al Azhar 8 Bekasi on April 20-21, 2017. In accordance with the problem studied, the affordable population in this study were students of class VIII in Bekasi, which was limited to a private junior high school, with 160 students. The selection of class VIII assumes that the level of thinking maturity is sufficient.

This study uses a multistage random sampling technique meaning that samples come from stratified populations where not all strata are drawn into samples but samples are taken at random. Choosing a sample in the multistage random sampling technique is done at least two stages. In the first stage, large groups or groups are selected. This group is designed to contain more population units other than those needed for the final sample and efficiency. In using multi-stage samples, researchers do not need a complete list of members in the target population which greatly reduces the cost of sample preparation. The list of members is needed only for the groups used in the final stage. The steps to determine the sample in this study are as follows: Stage 1, Choosing one of Private Junior High Schools in Bekasi City, by drawing lots.

Stage 2, Then random samples are taken back. so that a sample of 88 students was obtained. Data about habits of interacting via the internet is obtained by using a questionnaire. While the technique for obtaining data about English learning outcomes is taken from data in school archives/documents. The questionnaire used in this study contained several questions relating to the habits of students interacting through the internet.

The research procedure was conducted after obtaining a recommendation from the English Study Program Coordinator, STBA Cipto Hadi Pranoto. Then, the researchers submitted a request for research at the head of SMPI Al Azhar 8 Bekasi as a study place. After obtaining approval, the researcher explains the purpose and objectives of this study, and invites the respondent to sign the consent form being the respondent. Respondents who match the research criteria are welcome to fill in the research 
questionnaire sheet, after the study completed, the researcher asks for a statement letter of study completion from the school.

Data processing procedures are carried out through the validity and reliability test stages of the instrument test and questionnaire, data analysis test and research hypothesis test. The significance test of partial regression was done by taking into account the value in column $\mathrm{t}$ or column Sig in the Coefficient table. For partial regression the effect of $\mathrm{X} 1$ on $\mathrm{Y}$ is used row $\mathrm{t}$ value and Sig on row variable $\mathrm{X} 1$. If the Sig Column is used, the significance criteria are:

"If Sig $<0.05$ then the regression is significant" If Column $\mathrm{T}$ is used, the significance criteria are:

"If $t>$ t table then the regression is significant"

\section{Finding and Discussion}

The data of students' achievement in English was obtained from the PAS (Final Exam) score of 88 students who became the study sample. The lowest value obtained is 64 , the highest is 96 , the average is 83.78 , the median is 86.00 , the mode is 90 and the standard deviation is 8.479 .

Data recapitulation of the total score for each of the above variables is processed through the SPSS 20.0 for Windows program after a residual standard test is performed on the outlier data, then the summary data of English Learning Outcomes (Y) variables can be seen as in the table below:

Tabel 1 Data Description; Students Achievement in English

\begin{tabular}{lrr}
\hline \multirow{2}{*}{$N$} & \multicolumn{1}{c}{ Valid } & 88 \\
\cline { 2 - 3 } & Missing & 0 \\
\hline Mean & 83,78 \\
\hline Median & 86,00 \\
\hline Mode & 90 \\
\hline Std. Deviation & 8,479 \\
\hline Skewness &,- 607 \\
\hline Std. Error of Skewness &, 257 \\
\hline Kurtosis &,- 383 \\
\hline Std. Error of Kurtosis &, 508 \\
\hline Range & 32 \\
\hline Minimum & 64 \\
\hline Maximum & 96 \\
\hline
\end{tabular}

\section{Statistics English Final Exam Score}

Based on the above calculation results, it can be said that the Students' English achievement of SMPI Al Azhar 8 Bekasi is quite good. This is indicated by the acquisition of an average value of 83.78 . 
Furthermore, the histogram graph can be illustrated in Figure 2 A histogram is a picture in the form of a bar that shows the frequency of each data. Polygons show shapes approaching the normal curve, this shows that the data obtained in this study are normally distributed, because the shape of the curve approaches the normal curve shape.

Figure 2 Histogram Poligon Variabel Students' achievement in English

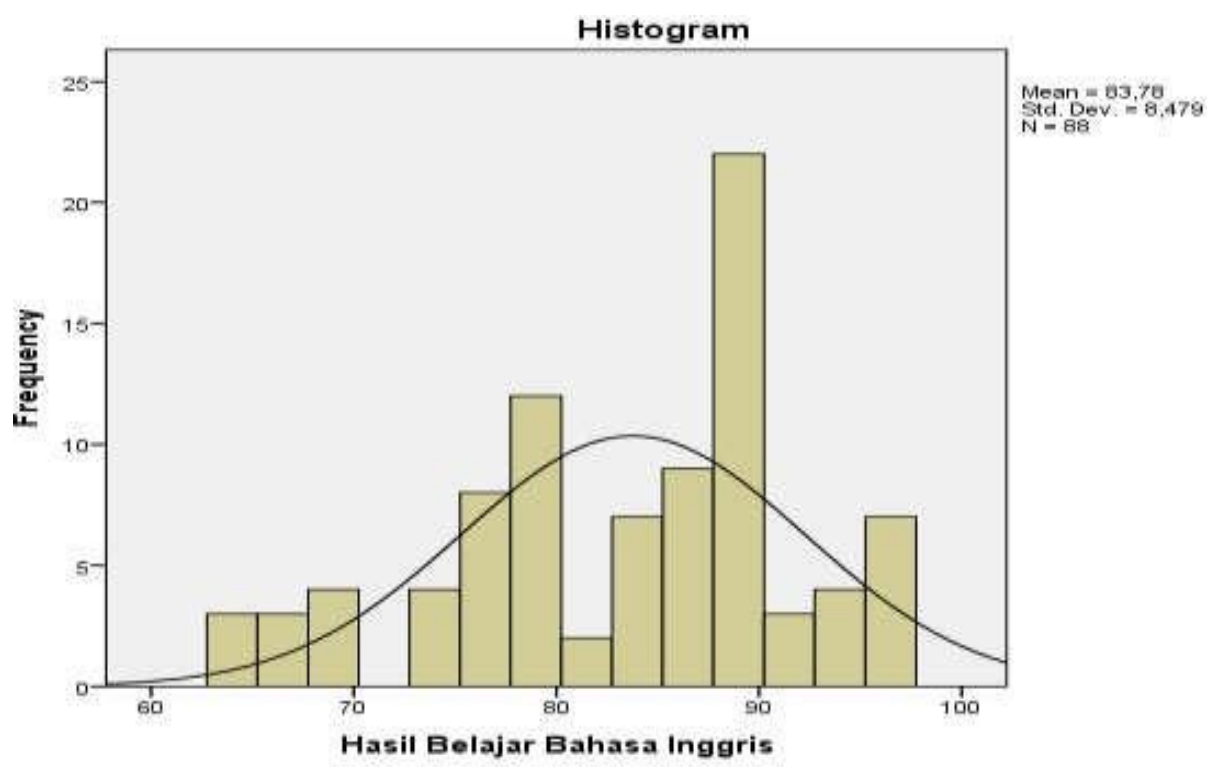

a. The Questionnaire Validation and Data Reliability

Data on the students' internet use habit were obtained from questionnaires answered by 88 students as respondents resulting in the lowest score of 78 , the highest score of 144 , the average score of 107.35 , the median of 109.00 , the mode of 110 and the standard deviation of 15,047

Tabel 3 The Data Description Variabel: Students' habit interaction by Internet

\begin{tabular}{lrr}
\hline \multirow{2}{*}{$N$} & \multicolumn{1}{c}{ Valid } & 88 \\
\cline { 2 - 3 } & Missing & 0 \\
\hline Mean & 107,35 \\
\hline Median & 109,00 \\
\hline Mode & $110 \mathrm{a}$ \\
\hline Std. Deviation & 15,047 \\
\hline Skewness &, 104 \\
\hline Std. Error of Skewness &, 257 \\
\hline Kurtosis &, 062 \\
\hline Std. Error of Kurtosis &, 508 \\
\hline Range & 66 \\
\hline Minimum & 78 \\
\hline Maximum & 144 \\
\hline
\end{tabular}




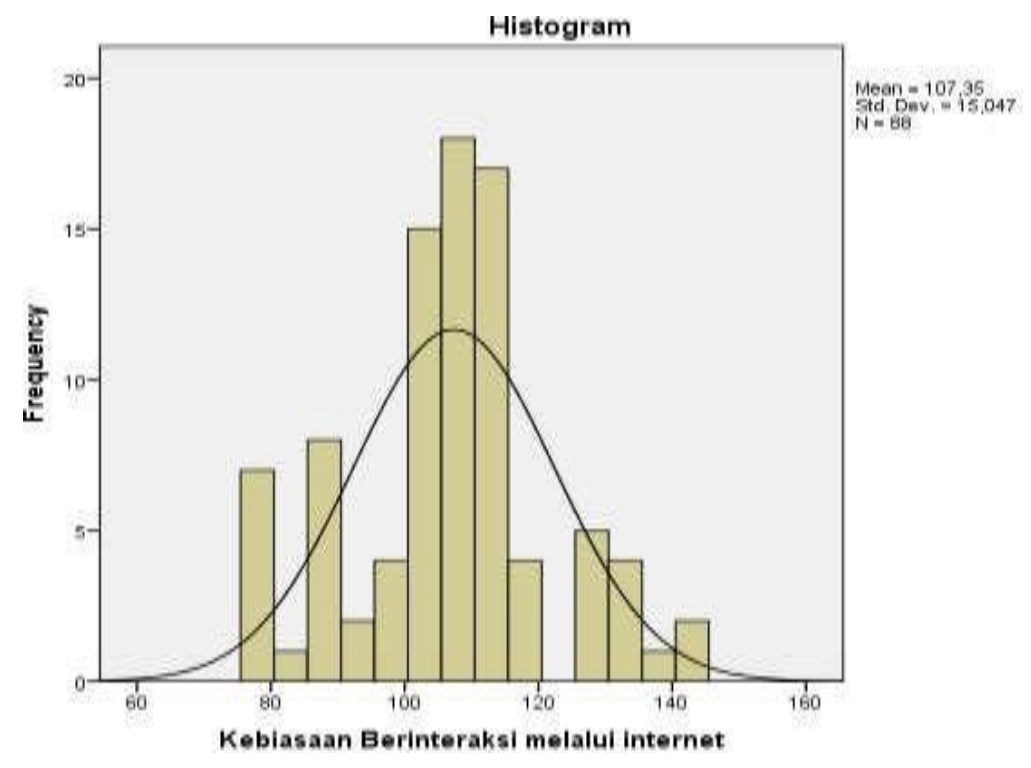

From the histogram and frequency polygon above, it can be concluded that the internet use habit of SMPI Al Azhar 8 students has a normal distribution.

b. Linearity Test

The regression of linearity test results between the Students' internet use habit with English achievement, calculated with SPSS 20.0 as follows:

Table 4 Test Results of Regression Linearity of Variable Y over X

\begin{tabular}{|c|c|c|c|c|c|c|c|}
\hline \multicolumn{8}{|c|}{ ANOVA Table } \\
\hline & & & $\begin{array}{l}\text { Sum of } \\
\text { Squares }\end{array}$ & Df & $\begin{array}{l}\text { Mean } \\
\text { Square }\end{array}$ & $\mathrm{F}$ & Sig. \\
\hline & & (Combined) & 1968,791 & 29 & 67,889 & 1,011 & ,472 \\
\hline English & Between & Linearity & 371,001 & 1 & 371,001 & 5,525 & ,022 \\
\hline \multirow{3}{*}{$\begin{array}{l}\text { Achieve } \\
\text { ment * } \\
\text { Internet } \\
\text { Use } \\
\text { Habit }\end{array}$} & Groups & $\begin{array}{l}\text { Deviation } \\
\text { from } \\
\text { Linearity }\end{array}$ & 1597,790 & 28 & 57,064 &, 850 & ,675 \\
\hline & \multicolumn{2}{|c|}{ Within Groups } & 3894,800 & 58 & 67,152 & & \\
\hline & Total & & 5863,591 & 87 & & & \\
\hline
\end{tabular}

Based on the calculation above, the result of Deviation from Linearity is obtained as: Fo $=0.850$ and Sig. $=0.675>0.05$. This has the understanding that the variable of Students' internet use habit with students' English learning achievement has a linear relationship.

c. Research Hypothesis Test

The effect of Habits interaction by the internet (X) on English achievement (Y): The testing hypothesis: 


$$
\begin{aligned}
& \mathrm{HO}_{\mathrm{O}}: \mathrm{p}_{\mathrm{y} 1}=0 \\
& \mathrm{H}_{1}: \mathrm{p}_{\mathrm{y} 1} \neq 0
\end{aligned}
$$

Meaning:

H0: There is no effect of the internet use habit on the English achievement

H1: there is an effect of the internet use habit on the English achievement

From table 4 it can be stated that there is a significant effect of the internet use habit on the English achievement. This is evidenced by the acquisition of $t$ value $=4.365$ and Sig. $0,000<0.05$.

Hence, the variable contribution of the internet use habit on the English achievement can be stated by the formula:

$\mathrm{KD}=$ Value $\mathrm{p}_{\mathrm{s} 2 \mathrm{y}} \times$ Partial Correlation Value $\left(\mathrm{r}_{\mathrm{s} 2 \mathrm{y}}\right) \times 100 \% \mathrm{KD}=$ $0,420 \times 0,501 \times 100 \%=21,04 \%$

From the calculation results above, it can be stated that the contribution of the internet use habit on the English achievement by $21.04 \%$.

From the finding, it can be concluded that the internet use habit has had a positive effect on the English achievement of Junior High School students in Bekasi. That is, the students' internet use habit has a significant effect on improving the learning achievement of students of SMPI Al Azhar 8 Bekasi.

Consequently, Teachers are suggested to follow current trends, where students today use more and more of the internet in everyday life. The internet cannot be separated in the daily routine of students, especially those who live in big cities. The internet use habit, which mostly uses English, can improve students' English skills indirectly.

The internet should be used positively to improve student learning achievement since they tend to enjoy learning by using interactive media that has internet technology access (Ramadhan, 2010).

\section{Conclusion}

The students of SMPI Al Azhar 8 Bekasi who often use and interact through the internet in a day have high levels of English achievement. Hence, there is a relationship between students' habit interaction by the internet with the level of student learning achievement at SMPI Al Azhar 8 Bekasi. 


\section{BIBLIOGRAFI}

Dogruer, Nazan, Eyyam, Ramadan, \& Menevis, Ipek. (2011). The use of the internet for educational purposes. Procedia-Social and Behavioral Sciences, 28, 606-611.

Fraenkel, Jack R., Wallen, Norman E., \& Hyun, Helen H. (2012). How to design and evaluate research in education (Vol. 7). McGraw-Hill New York.

Hariyadi, Hariyadi, \& Arliman, Laurensius. (2018). Peran Orangtua Dalam Mengawasi Anak Dalam Mengakses Media Internet Untuk Mewujudkan Perlindungan Hak Anak. Soumatera Law Review, 1(2), 267-281.

Jatileni, Malakia, \& Jatileni, Cloneria N. (2018). Teachers'perceptions On The Use Of Ict In Teaching And Learning: A Case Of Namibian Primary Education. Reports and Studies in Education, Humanities, and Theology, 33.

Jauhari, Jaidan. (2010). Upaya pengembangan usaha kecil dan menengah (UKM) dengan memanfaatkan e-commerce. Jurnal Sistem Informasi, 2(1), 1-12.

Panji, Aditya. (2014). Safety of the Use of Digital Media in Children and Youth in Indonesia. Retrieved from Kompas.com website: https://tekno.kompas.com/read/2014/02/19/1623250/Hasil.Survei.Pemakaian.Inter net.Remaja.Indonesia?page $=$ all

Ramadhan, H. (2010). Teknologi internet dalam pembelajaran bahasa Inggris. Retrieved April 21, 2017, from Basindo Blogspot website: http://basindo.a.blogspot.com

Riyana, Winda, \& Syaifudin, Syaifudin. (2014). Hubungan Intensitas Penggunaan Situs Jejaring Sosial Facebook dengan Prestasi Belajar pada Siswa dan Siswi Kelas VII di SMP Muhammadiyah Imogiri Bantul. STIKES’Aisyiyah Yogyakarta.

Urh, Marko, \& Jereb, Eva. (2014). Learning habits in higher education. Procedia-Social and Behavioral Sciences, 116, 350-355.

Yuliansyah, Yuliansyah. (2016). Meningkatkan Response Rate Pada Penelitian Survey Suatu Study Literature. Penerbit Change Publications. 